\title{
WATERSHED ROAD NETWORK ANALYSIS WITH AN EMPHASIS ON FIRE FIGHTING MANAGEMENT
}

\author{
Mohsen MOSTAFA, Shaban SHATAEE JOUIBARY ${ }^{\mathrm{b}}$, Majid LOTFALIAN ${ }^{c}$, Amir SADODDIN ${ }^{\mathrm{d}}$ \\ ${ }^{a, b}$ Department of Forestry, Faculty of Forest Sciences, Gorgan University of Agricultural Sciences \\ and Natural Resources, P.O. Box 386, Gorgan, Iran \\ 'Department of Forest Engineering, Faculty of Natural Resources, Sari University of Agricultural \\ Sciences and Natural Resources, P.O. Box 737, Sari, Iran \\ ${ }^{d}$ Department of Watershed Management, Faculty of Rangeland and Watershed, \\ Gorgan University of Agricultural Sciences and Natural Resources, P.O. Box 386, Gorgan, Iran
}

Submitted 27 Jul. 2016; accepted 10 Jan. 2017

\begin{abstract}
The aim of this study is fire hazard zoning the Chehel-Chay watershed and analysis of road network in order to fire-fighting management. Using effective factors on fire occurrence, the fire hazard map of the study area produced by support vector machine algorithm and then was divided into four hazard classes. The road length and type were investigated in the each fire hazard classes. The results showed that most of occurred fires are located in the close distances of roads and forest areas. The results showed that road types and land cover are important in fire occurrences and suppression. In high dangerous zone, the roads pass through forestlands, but in low dangerous zone, the roads are passing from farmlands. The roads do not cover the half of area and do not pass at two third of high hazard class zones. Therefore, appreciate road network planning is necessary according to fire-fighting management.
\end{abstract}

Keywords: Forest road, fire hazard map, fire-fighting vehicles, Support Vector Machine (SVM).

\section{Introduction}

Fire is one of the important components of natural ecosystems such as forests and rangelands (Sakr et al. 2010; Dlamini 2010). Forest fires can lead to destruction of environment, damages to human health and property, and endanger life, cause environment deterioration and soil losses (Bowyer et al. 2009; Fox et al. 2015) and create economic problems (Ozbygol, Bozer 2012). In Iran, fire is one of the most destructive occurring phenomena in forests and rangelands (Adab et al. 2013; Pourghasemi et al. 2016; Pourtaghi et al. 2015). The discussion about forest fire ignition can be divided into wildfire and anthropogenic fire (Verma et al. 2013). Most of fires occurring in Hyrcanian forests of Iran are anthropogenic fire (Pourghasemi et al. 2016).

Fire hazard mapping is important to proper planning to fire hazard reduction, management, and control of fire (Jaiswal et al. 2002). Several studies have been conducted to analyses forest fire using parametric and nonparametric algorithms (Table 1). Many studies have been used parametric algorithms such as linear regression (Dong et al. 2006; Oliveira et al. 2012), logistic regression
(Hernandez-Leal et al. 2006; Martinez et al. 2009; Zhang et al. 2010; Arndt et al. 2013; Guo et al. 2016), spatial clustering (Wu et al. 2015), generalized linear mixed models (Kwak et al. 2012; Boubeta et al. 2015), Monte Carlo simulations (Carmelm et al. 2009; Reineking et al. 2010), kernel methods (Amatulli et al. 2007; Kuter et al. 2011), and nonparametric algorithms as Random Forests (RF) (Massada et al. 2013; Pierce et al. 2012; Oliveira et al. 2012; Arpaci et al. 2014), Artificial Neural Networks (ANN) )Bisquert et al. 2012; Safi, Bouroumi 2013; Sahu 2015), and SVM for fire hazard mapping. Cortez and Morais (2007) used data mining (DM) approaches (SVM and RF) to predict the forest fires in the northeast region of Portugal using meteorological data. These studies showed that SVM algorithm had satisfactory performance in forest fire hazard mapping compared to other algorithms in general. Sakr et al. (2011) compared performance of ANN and SVM algorithms to reduce number of parameters and cost required system especially for developing countries and reported that SVM outperformed ANN based on cumulative precipitation and relative humidity.

Corresponding author: Shaban Shataee Jouibary

E-mail: shataee@yahoo.com 
Most human-caused fires occur in proximity to human settlements and road corridors (Soto 2012; Fox et al. 2015; Arpaci et al. 2014). Relationship among road network, fire occurring and fire management has been recognized for some times. Density of road and distance to roads influence the fire ignition (Nunes 2012; Chas-Amil et al. 2013; Guo et al. 2016). Roads provide access option inside forests in order to perform management practices, timber harvesting, and other services. Roads separate the ecosystem, create high contrast edges, (Forman, Alexander 1998), and reduce forest areas (Schonewald-Cox, Buechner 1992). Forest roads play significant role on wildfire prevention and fire suppression (Narayanaraj, Wimberly 2013), and creating linear gaps in forest (Spellerberg 2002) which changes microclimates closed to road (Chen et al. 1993). Relations between fire occurrences, fire management, and road have been studied in several researches (Table 2).

Çoban and Eker (2010) investigated the forest road before and after fire in burnt area, Turkey. Their analysis has explained that roads should be planned in fire sensitive regions and be facilitated management activities after fire event. Narayanaraj and Wimberly (2013) described effects of edge roads on the spatial pattern of burn severity in Okanogan-Wenatchee National Forest in Washington State. Nasiri (2012) examined the plan of skidding routes on fire fighting in DarabKola forest, north of Iran. Tian et al. (2013) investigated effective factors of forest fires in China; they explained $58 \%$ of occurred fires were located less than $5 \mathrm{~km}$ to roads. Roman and Martinez (2006) and Martinez et al. (2009) reported significant relationships between road density and forest fire in Mexico and Spain.

Table 1. Previous studies on fire hazard mapping

\begin{tabular}{|c|c|c|c|c|}
\hline \multirow[b]{2}{*}{ Author } & \multirow[b]{2}{*}{ Country } & \multicolumn{2}{|c|}{ Algorithms } & \multirow[b]{2}{*}{ Variables } \\
\hline & & $\begin{array}{l}\text { parametric } \\
\text { algorithm }\end{array}$ & $\begin{array}{c}\text { nonparametric } \\
\text { algorithms }\end{array}$ & \\
\hline Dong et al. (2006) & China & Linear regression & - & Fuel, topography, anthropogenic \\
\hline $\begin{array}{l}\text { Hernandez-Leal } \\
\text { et al. }(2006)\end{array}$ & Spain & $\begin{array}{l}\text { Logistic } \\
\text { regression }\end{array}$ & - & $\begin{array}{l}\text { Slope, altitude, insulation, proximity to road, } \\
\text { vegetation cover }\end{array}$ \\
\hline $\begin{array}{l}\text { Amatulli et al. } \\
(2007)\end{array}$ & Spain & Kernel methods & & Occurred fire, cover type, fire caused, weather \\
\hline Zhang et al. (2010) & China & $\begin{array}{l}\text { Logistic } \\
\text { regression }\end{array}$ & - & Topography, weather, human factor \\
\hline Kuter et al. (2011) & Turkey & Kernel methods & - & Information of occurred fire \\
\hline Sakr et al. (2011) & Lebanon & - & ANN, SVM & $\begin{array}{l}\text { Precipitation, relative humidity, solar radiation, } \\
\text { average wind speed }\end{array}$ \\
\hline Soto (2012) & Chile & Fuzzy logic & & $\begin{array}{l}\text { Spatial localization of the fires, road network, areas } \\
\text { with an urban- wild land interface }\end{array}$ \\
\hline Oliveira et al. (2012) & $\begin{array}{l}\text { Portugal, } \\
\text { Spain, } \\
\text { France, Italy } \\
\text { and Greece }\end{array}$ & Linear regression & Random forest & $\begin{array}{l}\text { Topography, land cover, climate, infrastructures, } \\
\text { demographic, socio-economic }\end{array}$ \\
\hline Kwak et al. (2012) & Korea & $\begin{array}{l}\text { Generalized linear } \\
\text { mixed models }\end{array}$ & - & $\begin{array}{l}\text { Topography, human factor, distance from road, forest } \\
\text { cover }\end{array}$ \\
\hline Bisquert et al. (2012) & Spain & Logistic regression & ANN & Monitor vegetation Status, land surface temperature \\
\hline Arndt et al. (2013) & Austria & Logistic regression & - & Socio-economic \\
\hline $\begin{array}{l}\text { Pourghasemi et al. } \\
\text { (2016) }\end{array}$ & Iran & $\begin{array}{l}\text { Mamdani fuzzy } \\
\text { logic, analytical } \\
\text { hierarchy process }\end{array}$ & & Topography, climate, land use, vegetation index \\
\hline Arpaci et al. (2014) & Austria & - & $\begin{array}{l}\text { Max Ent and } \\
\text { Random Forests }\end{array}$ & $\begin{array}{l}\text { Topography, vegetation, climate, socio-economic } \\
\text { datasets }\end{array}$ \\
\hline Wu et al. (2015) & China & Spatial clustering & - & Topography, climate, vegetation, occurred fire \\
\hline Boubeta (2015) & Spain & $\begin{array}{l}\text { Generalized linear } \\
\text { mixed models }\end{array}$ & & $\begin{array}{l}\text { Days without rain, Number of fires, Population size, } \\
\text { Cadastral parcel, Scrub area, Percentage of wet lands, } \\
\text { Percentage of wood lands }\end{array}$ \\
\hline Sahu (2015) & Portugal & - & ANN & $\begin{array}{l}\text { Fine fuel moisture code, duff moisture code, drought } \\
\text { code, initial spread index, fire behavior index }\end{array}$ \\
\hline Guo et al. (2016) & China & Logistic regression & & $\begin{array}{l}\text { Topographic, vegetation, climatic, infrastructure, } \\
\text { socioeconomic }\end{array}$ \\
\hline
\end{tabular}


Maingi and Henry (2007) studied important factors that have effects on wildfire in eastern Kentucky, USA. Their investigation showed that proximity to roads is an affective factor on forest fire ignition. Hoyo et al. (2011) reported most of fires start close to the roads in Madrid, Spain. Verma et al. (2013) found that high road connection led to more forest fire in Missouri forest division in India during 2000 to 2011.

The Chehel-Chay watershed is one of the areas that have different natural disasters such as fire occurring due

Table 2. Different studies, which are showed relationships between fire occurrences, fire management, and roads

\begin{tabular}{|c|c|c|c|c|}
\hline \multirow[b]{2}{*}{ Author } & \multirow[b]{2}{*}{ Year } & \multirow[b]{2}{*}{ Country } & \multicolumn{2}{|c|}{ Subject } \\
\hline & & & $\begin{array}{c}\text { fire } \\
\text { occur- } \\
\text { rences }\end{array}$ & $\begin{array}{c}\text { fire } \\
\text { mana- } \\
\text { gement }\end{array}$ \\
\hline Martinez et al. & 2009 & Spain & - & - \\
\hline Arienti et al. & 2009 & Canada & $\bullet$ & - \\
\hline $\begin{array}{l}\text { Çoban and } \\
\text { Eker }\end{array}$ & 2010 & Turkey & $\bullet$ & $\bullet$ \\
\hline $\begin{array}{l}\text { Avila-Flores } \\
\text { et al. }\end{array}$ & 2010 & Mexico & $\bullet$ & - \\
\hline Hoyo et al. & 2011 & Spain & $\bullet$ & \\
\hline $\begin{array}{l}\text { Narayanaraj } \\
\text { and Wimberly }\end{array}$ & 2011 & USA & $\bullet$ & - \\
\hline $\begin{array}{l}\text { Zumbrunnen } \\
\text { et al. }\end{array}$ & 2012 & Switzerland & $\bullet$ & - \\
\hline Massada et al. & 2013 & USA & $\bullet$ & \\
\hline Nasiri & 2012 & Iran & - & $\bullet$ \\
\hline Tian et al. & 2013 & China & $\bullet$ & - \\
\hline $\begin{array}{l}\text { Narayanaraj } \\
\text { and Wimberly }\end{array}$ & 2013 & USA & $\bullet$ & - \\
\hline Liu et al. & 2015 & China & $\bullet$ & - \\
\hline Barni et al. & 2015 & Brazil & $\bullet$ & - \\
\hline
\end{tabular}

to special ecological, economical, and social conditions and containing various land covers and human activities. In the study area, the road network with different road types are spatially distributed in the whole of watershed. In addition to preparing accessibility to human settlements for different needs, the roads and its network are playing important role both in fire occurring due to preparing accessing people to whole area and play key role in suitable fire fighting due to preparing facilities for fire fighters and vehicles. The investigation on fire risk assessment of a watershed and its zoning based on fire probability as well as performance analysis of current road network in order to achieve fire-fighting management is very necessary for watershed management. Therefore, the aim of the current study is (1) zoning the Chehel-Chay watershed based on fire hazard probability using support vector machine $\operatorname{SVM}((2)$, analysis of road network in order to Fire Fighting Management (FFM) in different land covers.

\section{Materials and methods}

The Chehel-Chay Watershed is located in Minoodasht County in the Golestan Province, Northern Iran. The area of watershed is about 25680 hectares and is located between latitudes $36^{\circ}, 59^{\prime}$ to $36^{\circ}, 17^{\prime} \mathrm{N}$, and longitudes $55^{\circ}$, $22^{\prime}$ to $55^{\circ}, 37^{\prime} \mathrm{E}$ (Fig. 1). The elevation above sea level is ranging 190 to $2750 \mathrm{~m}$. The dominant land-cover vegetation of watershed is forest in the northern part, and mixed rangeland and forest in southern part. The climate type varies from temperate to semi-humid (Pourghasemi et al. 2016). Average annual precipitation of the study area is approximately $750 \mathrm{~mm}$. The main land uses in the watershed is include forest (67\%), croplands $(28.8 \%)$, grassland (4.09\%), and human residential areas $(0.53 \%)$.

The datasets and methodology are shown in (Fig. 2). The flowchart shows two steps of the study: (1) Fire hazard

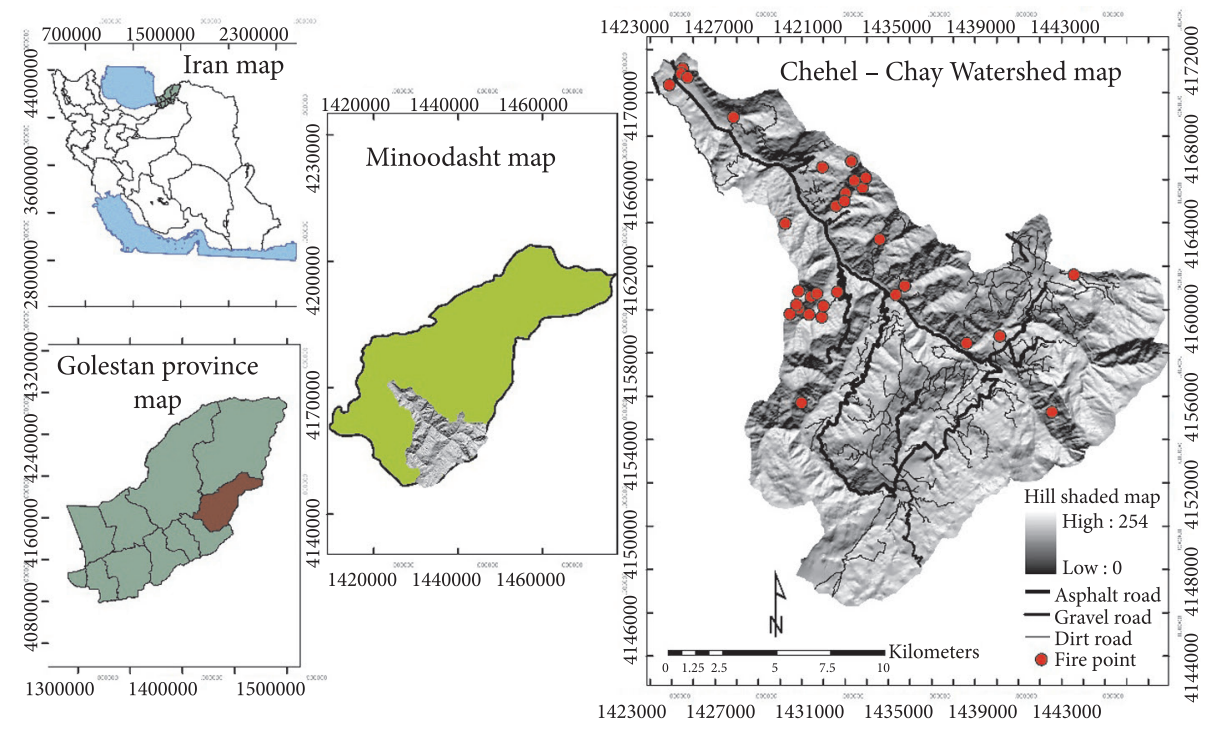

Fig. 1. Location the study area in the Golestan Province, Northern Iran, and location of occurred fires in the past years 
mapping by SVM (2) assessing the road network distribution in the study area according to FFM.

In order to produce a fire hazard probability map, the effective factors on fire occurrences including climate, topography, vegetation, human factors, distance to water recourse were identified and prepared from different sources and using various techniques in addition OFFP in the recent past years (Table 3 ).

Climate influences the fire regime through several processes (Deng et al. 2013). Data related to Climatology is complex in forest areas and many microclimates can be observed in these areas (Cottle 2007). In the current study, wind direction, and speed, maximum absolute temperature, monthly average evaporation, minimum relative humidity, and monthly average precipitation of autumn were used as climate related data because of accruing about $70 \%$ of fires in October, November, and December. The climate maps were created using continues data (Fig. 3).

Topography is a significant physiographic factor that influences the fire spreading and this occurrence of fire indirectly (Jaiswal et al. 2002) and affects the climate on the landscape and fuel availability (Vasilakos et al. 2009). Elevation, slope, and aspect as topographical factors influence the ignition of forest fires (Lee et al. 2004; Kwak et al. 2012). In this research, topographic variables including elevation, slope, and aspect were used to create fire hazard map. The contour lines from, National Cartographic Center (NCC) were used to obtain Digital Elevation Model (DEM), slope, and aspect maps. Topographical characteristics of the study area are shown in (Fig. 4).

Vegetation is one of the main environmental variables that affect fire-regime (Amatulli et al. 2007; Tuček, Majlingová 2009). Vegetation (dead or alive covers) prepares the fuel for fire ( $\mathrm{Wu}$ et al. 2015) and causes some

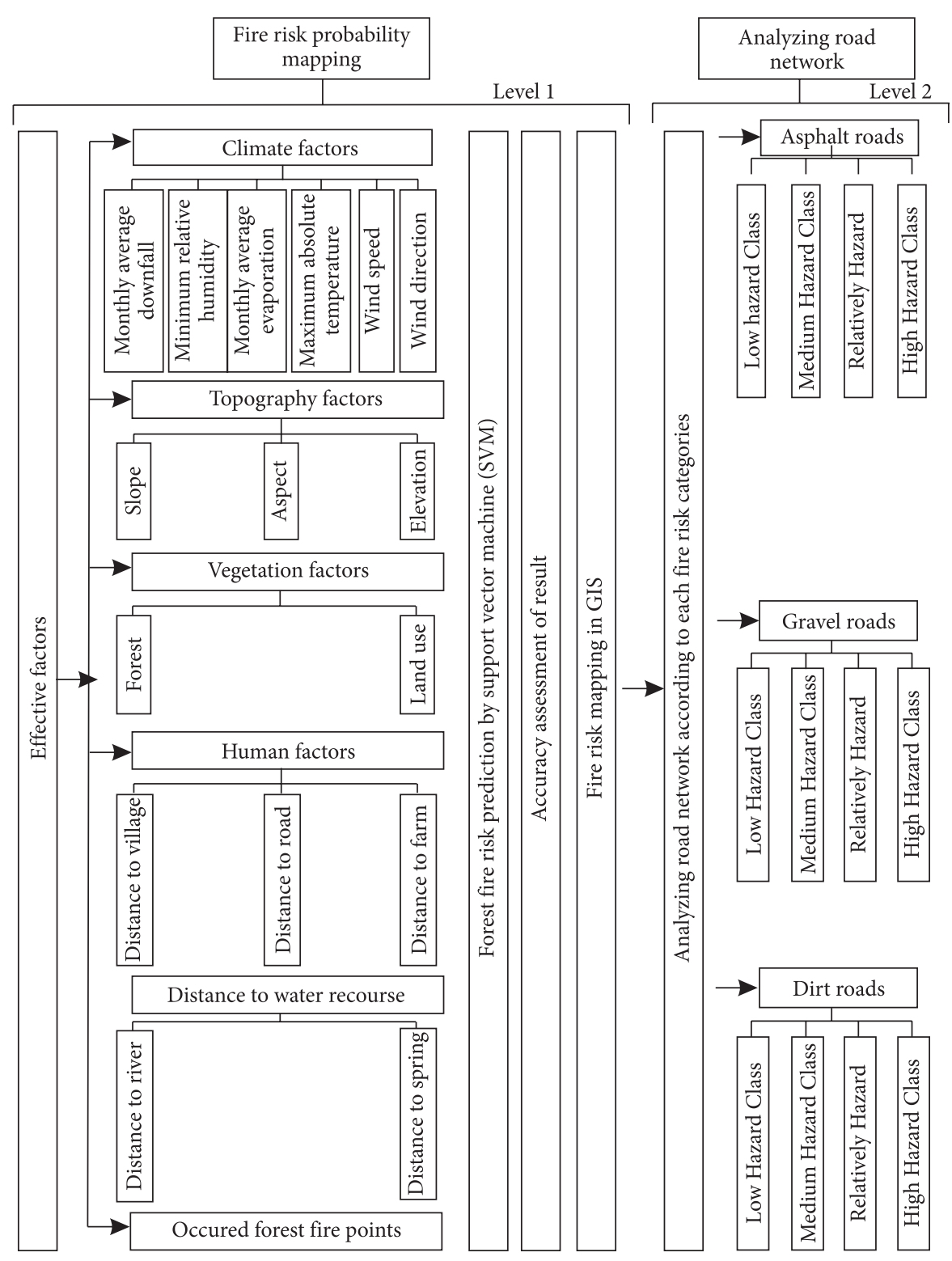

Fig. 2. Flowchart of the implemented methodology 
Table 3. Variables used for fire hazard probability mapping (FRPM)

\begin{tabular}{|c|c|c|c|}
\hline Variable type & Variable name & $\begin{array}{c}\text { Data format/ } \\
\text { Resolution/ Scale }\end{array}$ & Source of data \\
\hline Climatic & $\begin{array}{l}\text { Monthly dominant wind direction } \\
\text { Monthly maximum wind speed } \\
\text { Monthly maximum absolute } \\
\text { temperature } \\
\text { Monthly average evaporation } \\
\text { Monthly minimum relative humidity } \\
\text { Monthly average precipitation }\end{array}$ & Excel data & $\begin{array}{l}\text { Iranian Meteorological Organization(IRIMO) } \\
\text { Golestan Regional Water Authority (GRWA) }\end{array}$ \\
\hline $\begin{array}{l}\text { Topographic } \\
\text { map }\end{array}$ & $\begin{array}{l}\text { Elevation } \\
\text { Slope } \\
\text { Aspect }\end{array}$ & Raster/10 m & National Cartography Center (NCC) \\
\hline Vegetation & $\begin{array}{l}\text { Forest type } \\
\text { Forest and non-forest map }\end{array}$ & Vector/ 1:25000 & $\begin{array}{l}1 \text { - Forest management plan. } 2 \text { - Integrated } \\
\text { management of the Chehel-Chay Watershed. } \\
3 \text { - Extensive fieldwork. } 4 \text { - Satellite image, } \\
\text { National Cartographic Center (NCC) }\end{array}$ \\
\hline Infrastructure & $\begin{array}{l}\text { Distance to road } \\
\text { Distance to village } \\
\text { Distance to recreational sites } \\
\text { Distance to agricultural areas }\end{array}$ & Vector/ 1:25000 & $\begin{array}{l}1 \text { - Forest management plan. } 2 \text { - Integrated } \\
\text { management of the Chehel-Chay Watershed. } \\
3 \text { - Extensive fieldwork. } 4 \text { - Satellite image, } \\
\text { National Cartographic Center (NCC) }\end{array}$ \\
\hline Water recourse & $\begin{array}{l}\text { Distance to river } \\
\text { Distance to spring }\end{array}$ & Vector/ 1:25000 & $\begin{array}{l}1 \text { - Forest management plan. } 2 \text { - Integrated } \\
\text { management of the Chehel-Chay Watershed. } \\
3 \text { - Extensive fieldwork. } 4 \text { - Satellite image, } \\
\text { National Cartographic Center (NCC) }\end{array}$ \\
\hline $\begin{array}{l}\text { Occurred } \\
\text { forest fire }\end{array}$ & - & $\begin{array}{l}\text { Point, Polygon, } \\
\text { Excel data }\end{array}$ & $\begin{array}{l}1 \text { - Extensive fieldwork. 2. Archive of Department } \\
\text { of Natural Resources and Watershed (DNRW), } \\
\text { Golestan province }\end{array}$ \\
\hline
\end{tabular}
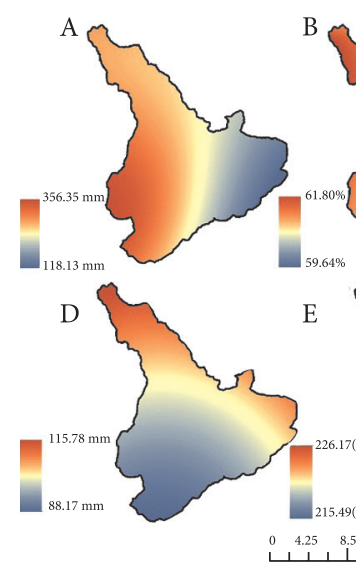
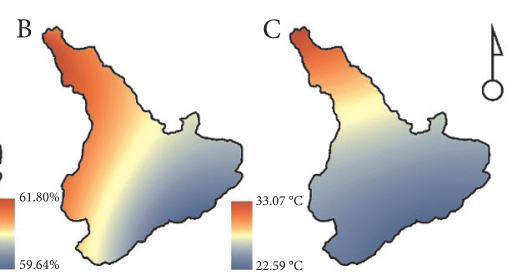

F

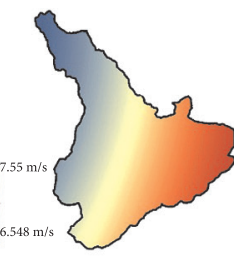

Fig. 3. Climatology characteristics of the Chehel-chay Watershed for period of October-December: Precipitation $(\mathrm{mm})(\mathrm{A})$, Minimum relative humidity (\%) (B), Maximum absolute temperature (Celsius) (C), Evaporation (mm) (D), Wind direction (Degree) (E), Wind speed $(\mathrm{km} / \mathrm{h})(\mathrm{F})$

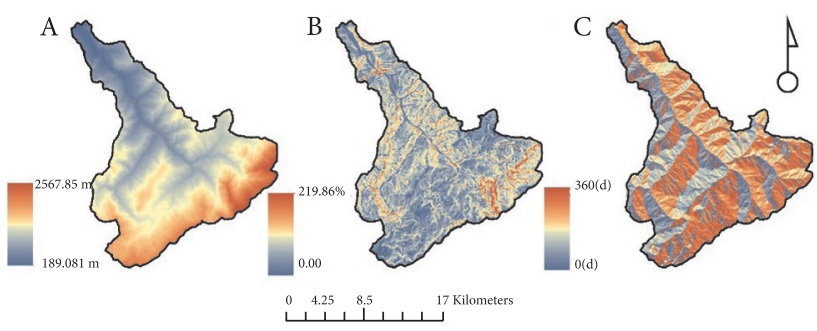

Fig. 4. Topographical characteristics of the Chehel-chay Watershed: Elevation (m) (A), Slope (\%) (B), Aspect (Degree) (C) problems for forest fire fighting (Chen, Di 2015). The vegetation factor in the study area was used in two maps: land use map and forest type map. The land use map was classified into two classes, forest and non-forest, and land cover was classified into nine classes, Carpineo-Parrotium, Carpinetum-Betulus, Quereteo-Castaneifolia, QuereteoCarpinetum, Carpinetum-schuschaensis, Petrocaryo- Alnetum, Pinus-Cupressus (reforestation), Grassland and nonforest (Fig. 5).

Human activities such as agricultural, human settlements and recreational activities are very important in fire occurrence (Amatulli et al. 2007). The main causes of forest fires in Japan, China, USA, Brazil, and Europe are related to human activities (Martinez et al. 2009; Barni et al. 2015). Fire regimes are affected by human activities during last century (Chen et al. 2015) and more than $80 \%$ of fires are caused by human activity (FAO 2007). The human

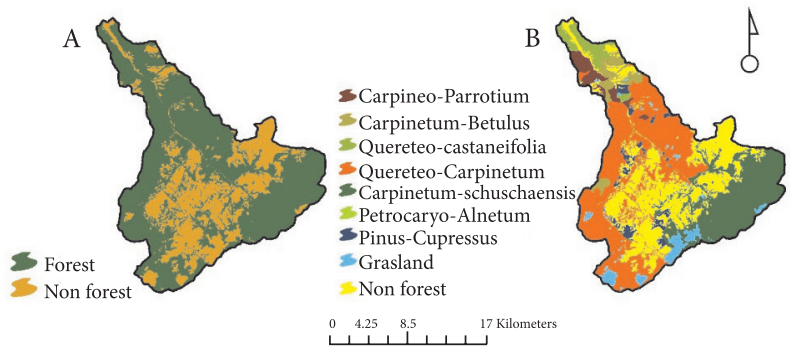

Fig. 5. Vegetation characteristics of the Chehel-chay Watershed; Landaus map (A), Landover maps (B) 
factors considered in this research are distance to roads, villages, recreational sites and agricultural areas (horticultures, irrigated and dry farms, rice paddies, livestock) (Fig. 6).

Water sources and access to its are one of the main factors that affect the forest fire (Jaiswal et al. 2002) as well as an important factor that prevent the spread of forest fire (Češljar, Stevović 2015). In this research, distance to rivers and springs were used as water factor (Fig. 7).

The existing road network map was created on 1:25,000 scale (NCC), using satellite image, and mapping by GPS. The road network was classified into three classes including asphalt, gravel, and dirt roads by through filed visit road (Fig. 1).

Road network density is one of factors used to find correlation between lightning fire and road network (Arienti et al. 2009). The road network density was calculated for the study area, fire hazard classes, and land use classes in whit in fire hazard probability map classes (Eq. (1)):

$$
N D=\frac{L}{A},
$$

where $N D$ - road density; $L$ - length of road network (meters); $A$ - area (ha).

Forest roads provide access for ground and aerial firefighting equipment (Kapusniak, Majlingová 2014). In the study area, all road types can be used for fire extinguishing, the maximum distance was 500 meters from the roads. Deployment of ground mobile fire-fighting equipment to fight the fire was possible on 100 meters to asphalt and gravel roads. In order to find the area that covered with the road network considering firefighting buffer map, 500 meters from both sides of the roads generated using ArcGIS 10.1. Then the cover percentage of road network was calculated (Eq. (2)):

$$
E(\%)=\frac{a}{A} \cdot 100,
$$

where $E(\%)$ - cover percentage of road network for firefighting; $A$ - total area of study area; $a$ - area covered with road network.

Using effective factors on fire occurrence including climate, topography, vegetation, human factor, factors related to water sources and the occurred forest fire points, the fire hazard probability map of the study area produced by support vector machine (SVM) algorithm. The specified grid search using v-fold cross-validation method used to find suitable parameters, i.e. epsilon $(\varepsilon)$ and capacity (C) with fixed gamma that would produce high-accuracy results. Then, the fire hazard map was divided into four classes including low hazard class (LHC), medium hazard class (MHC), relatively hazard class (RHC), and high hazard class (HHC). The road type network (asphalt, gravel, and dirt roads) and land covers were analyzed according to each fire hazard categories.

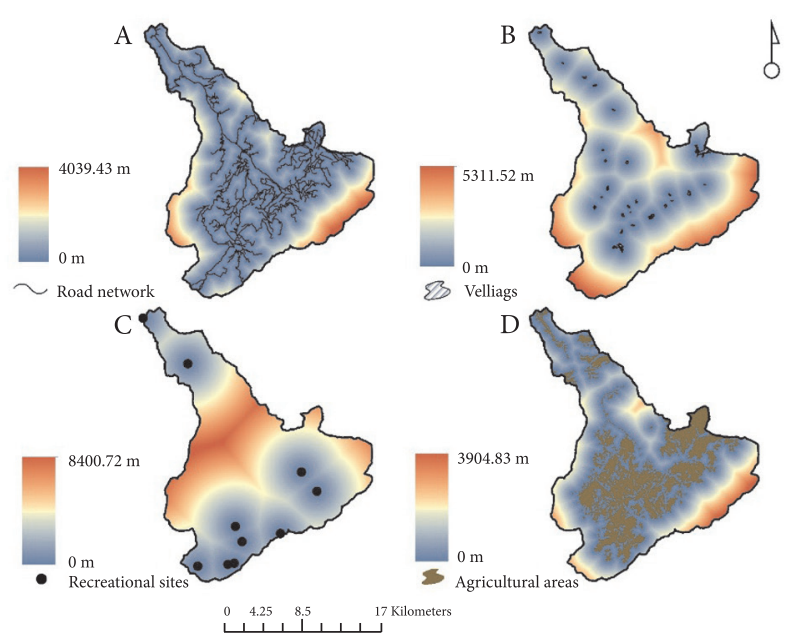

Fig. 6. Human factors of the Chehel-chay Watershed: Distance to road (A), Village (B), Recreational sites (C), Agricultural areas (D)

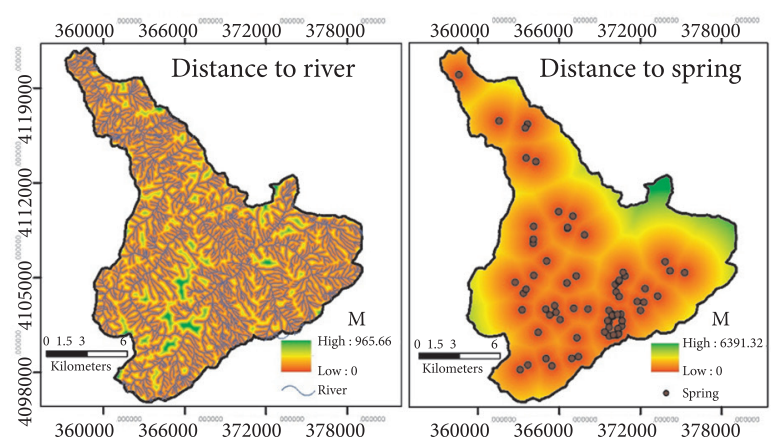

Fig. 7. Factors related to water recourses of the Chehel-chay Watershed: Distance to river (A), Springs (B)

\section{Results and discussion}

The total length of the road network in the study area is $337.07 \mathrm{~km}$. Considering road lengths and density; most of the roads were dirt roads, followed by asphalt and gravel roads. The length and density of dirt roads are $243.54 \mathrm{~km}$ and $9.47 \mathrm{mha}^{-1}$, respectively (Table 3). The asphalt and gravel roads as public roads were constructed in order to access to villages whereas all dirt roads were used to access farmlands, livestock, and recreational sites. There are not roads that not constructed specifiable for forest operation in the study area.

Table 3. Road network length and density of the Chehel-chay Watershed

\begin{tabular}{lcc}
\hline Road surface type & Length $(\mathrm{km})$ & Density $\left(\mathrm{mha}^{-1}\right)$ \\
\hline Asphalt & 82.87 & 3.23 \\
\hline Gravel & 10.66 & 0.42 \\
\hline Dirt & 243.54 & 9.47 \\
\hline Total & 337.07 & 13.12 \\
\hline
\end{tabular}


More than half of the study area (58\%) is covered by road network for the purpose FFM. On other hand about 14900 ha of the study area is accessible in term of purpose. Figure 8a indicates the areas were accessible and inaccessible by road network. In other hand, $42 \%$ of watershed dose not covered by roads. Therefore, road network planning is necessary for this area according to FFM. As discussed by Kapusniak and Majlingová (2014) new road planning suitable to fighting fire in natural conditions is necessary. The results indicated that the LHC class is the largest class in fire hazard probability map (10640.5 ha, $42 \%)$, then followed by HHC (7995.8 ha, 31.5\%), MRHC (3959.8 ha, 15\%) and RHC (3083.8 ha, 12\%) (Table 4 and Fig. $8 \mathrm{~b}$ ). The results show that $83 \%$ of past fires are located in $\mathrm{HHC}$ class and in the distances of less than $1000 \mathrm{~m}$ to roads. The finding of this research in line with what has been stated by (Spellerberg 2002; Narayanaraj, Wimberly 2013) that the roads have important effects on ignition in forest.

Table 4. Fire hazard classes area of the Chehel-chay Watershed

\begin{tabular}{ccccc}
\hline $\begin{array}{c}\text { Fire } \\
\text { hazard }\end{array}$ & LHC & MRHC & RHC & HHC \\
Area (ha) & 10640.49 & 3959.853 & 3083.813 & 7995.843 \\
\hline
\end{tabular}

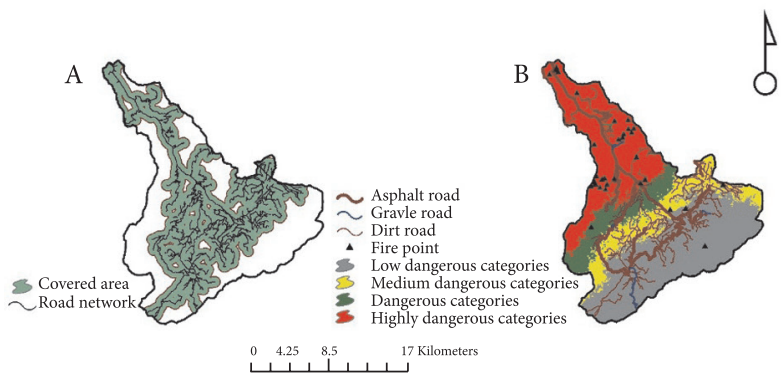

Fig. 8. Cover area of road network (A), Road network on the fire hazard probability map (B)

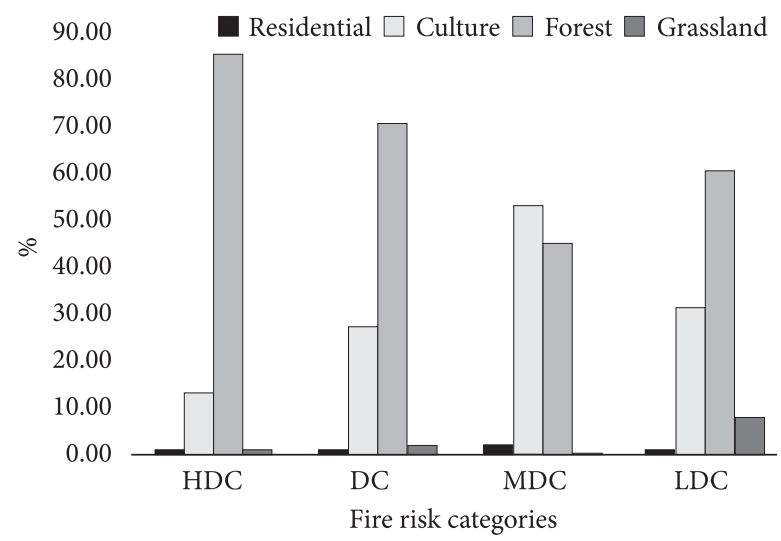

Fig. 9. Percentage of land use on the fire hazard classes of the Chehel-chay Watershed
The results indicate that 85.51 percent of $\mathrm{HHC}$ and 70.18 percent of RHC were covered by forest (productive forest, conservative forest, and reforestation). The conservative forests, agricultural lands were the largest land use in the LCD (69.09\%) and MRHC (53.2\%), respectively (Table 5, Fig. 9). The analysis of land use classes according to the fire hazard probability map fire were in line with previous studies (Carmo et al. 2011; Pourghasemi et al. 2016). Forests were the more fire prone land use; human settlements areas and agriculture land use (dry farming, Rice field, and garden) were the less susceptible land uses, respectively.

Table 5. Area of land uses on the fire hazard classes of the Chehel-chay Watershed

\begin{tabular}{lcccc}
\hline $\begin{array}{l}\text { Land use/Fire } \\
\text { hazard classes }\end{array}$ & LHC (ha) & $\begin{array}{c}\text { MRHC } \\
\text { (ha) }\end{array}$ & RHC (ha) & $\begin{array}{c}\text { HHC } \\
\text { (ha) }\end{array}$ \\
\hline $\begin{array}{l}\text { Human } \\
\text { settlements }\end{array}$ & 62.91 & 53.51 & 7.45 & 22.68 \\
\hline Culture & 3330.36 & 2106.46 & 842.94 & 1036.26 \\
\hline $\begin{array}{l}\text { Productive } \\
\text { forest }\end{array}$ & 0 & 0 & 56.82 & 1803.69 \\
\hline $\begin{array}{l}\text { Conservative } \\
\text { forest }\end{array}$ & 6394.29 & 1787.42 & 1965.38 & 893.58 \\
\hline $\begin{array}{l}\text { Reforestation } \\
\text { Grassland }\end{array}$ & 0 & 1.95 & 142.05 & 139.62 \\
\hline
\end{tabular}

The largest and lowest road densities belong to MRHC and HHC, respectively. The largest densities of asphalt roads density belong to HHC (3.74 $\left.\mathrm{mha}^{-1}\right)$ and RHC $\left(4.41 \mathrm{mha}^{-1}\right)$. Table 6 indicates the detail of each road on the fire hazard probability map.

Table 6. Detailed length and density of road network on the fire hazard probability map of the Chehel-chay Watershed

\begin{tabular}{|c|c|c|c|c|c|}
\hline \multicolumn{2}{|c|}{$\begin{array}{c}\text { Road/Fire hazard } \\
\text { classes }\end{array}$} & \multirow{2}{*}{$\begin{array}{c}\text { LHC } \\
29.6\end{array}$} & \multirow{2}{*}{$\begin{array}{c}\text { MRHC } \\
9.83\end{array}$} & \multirow{2}{*}{$\begin{array}{r}\text { RHC } \\
13.62\end{array}$} & \multirow{2}{*}{$\begin{array}{l}\mathrm{HHC} \\
29.93\end{array}$} \\
\hline $\begin{array}{l}\text { Length } \\
\text { of road }\end{array}$ & $\begin{array}{l}\text { Asphalt road } \\
(\mathrm{km})\end{array}$ & & & & \\
\hline $\begin{array}{l}\text { network } \\
\text { on the }\end{array}$ & $\begin{array}{l}\text { Gravel road } \\
(\mathrm{km})\end{array}$ & 7.85 & 0.32 & 0.25 & 2.22 \\
\hline $\begin{array}{l}\text { hazard } \\
\text { classes }\end{array}$ & $\begin{array}{l}\text { Dirt road } \\
(\mathrm{km})\end{array}$ & 113.21 & 69.82 & 22.56 & 37.94 \\
\hline \multirow{4}{*}{$\begin{array}{l}\text { Density } \\
\text { of road } \\
\text { network } \\
\text { on the } \\
\text { fire } \\
\text { hazard } \\
\text { classes }\end{array}$} & $\begin{array}{l}\text { Asphalt road } \\
(\mathrm{M} / \mathrm{Ha})\end{array}$ & 2.79 & 2.49 & 4.41 & 3.74 \\
\hline & $\begin{array}{l}\text { Gravel road } \\
(\mathrm{m} / \mathrm{Ha})\end{array}$ & 0.74 & 0.08 & 0.08 & 0.28 \\
\hline & $\begin{array}{l}\text { Dirt road } \\
(\mathrm{m} / \mathrm{Ha})\end{array}$ & 10.64 & 17.64 & 7.32 & 4.75 \\
\hline & Total & 14.17 & 20.13 & 11.81 & 8.77 \\
\hline
\end{tabular}


About $111.39 \mathrm{~km}$ of roads were located in agriculture areas (dry farming, Rice field, and garden) and $29.81 \mathrm{~km}$ of roads were located in forest areas (conservative forest) in LCD classes and density of these roads were $33.54 \mathrm{~km} / \mathrm{ha}$ and $4.66 \mathrm{~m} / \mathrm{ha}$, respectively. In MRHC classes, the road density in agriculture areas and forest areas (conservation forest) was $31 \mathrm{~m} / \mathrm{ha}$ and $7.89 \mathrm{~m} / \mathrm{ha}$, respectively. In RHC classes, the road density in agriculture areas are $28 \mathrm{~m} / \mathrm{ha}$ and in forest areas (conservative forest, productive forest, and reforestation) are $64.3 \mathrm{~m} / \mathrm{ha}$. In HHC classes, the road density in agriculture areas are $18.62 \mathrm{~m} / \mathrm{ha}$ and in forest areas (conservative forest, productive forest, and reforestation) are $39.19 \mathrm{~m} / \mathrm{ha}$ (Table 7, Fig. 10). Most of the roads in MRHC and LHC were dirt roads, which are the basic communication networks among agriculture areas. However, the most of fire occurred and asphalt roads are located in the HHC and RHC that are forest areas land use. In fact, the asphalt roads are the principle route to connect the study area to center of county (Minoodasht city). It can be concluded that type of road and land cover are important in fire ignition in wild land. The main roads increases human pressure in natural resources lands and lead to fire ignition by accident and negligence (Soto 2012; Renard et al. 2012).

The MRHC class has the largest cover percentage of road network (64.24\%) that road network covered 2543.65 ha of the area. The road network covered the $34.5 \%$ of the HHC class area (Table 7).

Table 7. Cover percentage of road network in fire hazard classes of the Chehel-chay Watershed

\begin{tabular}{lcccc}
\hline $\begin{array}{c}\text { Fire hazard } \\
\text { classes }\end{array}$ & HHC & RHC & MRHC & LHC \\
\hline $\begin{array}{l}\text { Road network } \\
\text { cover area (ha) }\end{array}$ & 2758.30 & 1156.74 & 2543.65 & 4674.69 \\
\hline $\begin{array}{l}\text { Road network } \\
\text { cover percentage }\end{array}$ & 34.50 & 37.52 & 64.24 & 43.93 \\
\hline
\end{tabular}

The lowest cover percentage of road network in forest areas are belonged to LHC class. In MRHC, class $37.31 \%$ conservation forest and $99.75 \%$ of reforestation areas are covered by road network. In RHC class, $91.69 \%$ of productive forest, $18.51 \%$ of conservation forest, and $67.44 \%$ of reforestation area covered by road network. In HHC class, $33.74 \%$ of productive forest, $24.43 \%$ of conservation forest, and $55.75 \%$ of reforestation areas covered by road. Table 8 and Figure 11 show the detail cover percentage of road network in land use class in fire hazard classes. Roads provide access to forest and help to fire ignitions but they reduce burn severity and prevent the fire spread (Renard et al. 2012; Narayanaraj, Wimberly 2013). The lowest cover percentage of rod network in our study area belong to forestland use in $\mathrm{HHC}$, this results are in line with (Narayanaraj, Wimberly 2011).

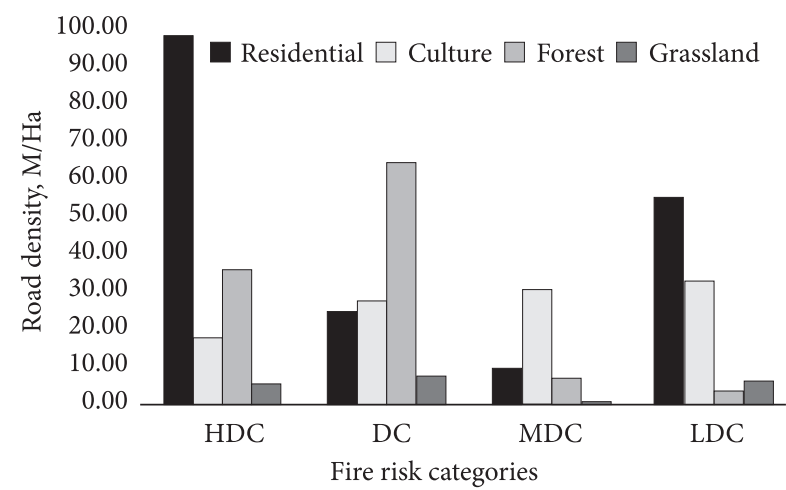

Fig. 10. Road density in fire risk categories

Table 8. Detailed cover percentage of road network in land use class in fire hazard classes of the Chehel-chay Watershed

\begin{tabular}{|c|c|c|c|c|}
\hline $\begin{array}{c}\text { Fire } \\
\text { hazard } \\
\text { classes }\end{array}$ & Land use & Area (ha) & $\begin{array}{c}\text { Area } \\
\text { coverage } \\
\text { (ha) }\end{array}$ & Cover (\%) \\
\hline \multirow{4}{*}{ LHC } & $\begin{array}{l}\text { Human } \\
\text { settlements }\end{array}$ & 62.91 & 62.48 & 99.32 \\
\hline & Culture & 3330.36 & 2874.49 & 86.31 \\
\hline & $\begin{array}{l}\text { Conservation } \\
\text { forest }\end{array}$ & 6394.29 & 1552.15 & 24.27 \\
\hline & Grassland & 852.93 & 185.57 & 21.76 \\
\hline \multirow{5}{*}{ MRHC } & $\begin{array}{l}\text { Human } \\
\text { settlements }\end{array}$ & 53.51 & 51.62 & 96.47 \\
\hline & Culture & 2106.46 & 1819.29 & 86.37 \\
\hline & $\begin{array}{l}\text { Conservative } \\
\text { forest }\end{array}$ & 371787.42 & 666.87 & 37.31 \\
\hline & Reforestation & 1.95 & 1.95 & 99.75 \\
\hline & Grassland & 10.51 & 3.92 & 37.29 \\
\hline \multirow{6}{*}{ RHC } & $\begin{array}{l}\text { Human } \\
\text { settlements }\end{array}$ & 7.45 & 7.45 & 99.96 \\
\hline & Culture & 842.94 & 625.75 & 74.23 \\
\hline & $\begin{array}{l}\text { Productive } \\
\text { forest }\end{array}$ & 56.82 & 52.10 & 91.69 \\
\hline & $\begin{array}{l}\text { Conservative } \\
\text { forest }\end{array}$ & 1965.38 & 363.77 & 18.51 \\
\hline & Reforestation & 142.05 & 95.80 & 67.44 \\
\hline & Grassland & 69.17 & 11.87 & 17.16 \\
\hline \multirow{6}{*}{$\mathrm{HHC}$} & $\begin{array}{l}\text { Human } \\
\text { settlements }\end{array}$ & 22.68 & 19.94 & 87.93 \\
\hline & Culture & 1036.26 & 773.46 & 74.64 \\
\hline & $\begin{array}{l}\text { Productive } \\
\text { forest }\end{array}$ & 1803.69 & 608.62 & 33.74 \\
\hline & $\begin{array}{l}\text { Conservative } \\
\text { forest }\end{array}$ & 4893.58 & 1244.42 & 25.43 \\
\hline & Reforestation & 139.62 & 77.83 & 55.75 \\
\hline & Grassland & 100.01 & 34.03 & 34.02 \\
\hline
\end{tabular}




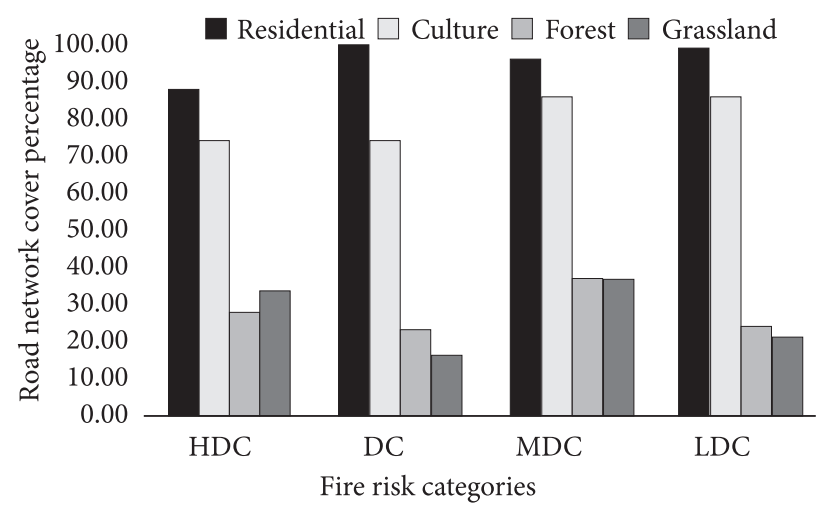

Fig. 11. Cover percentage of road network in land use class in fire risk categories

\section{Conclusions}

This study is about fire risk, management, and road network in a watershed (i.e. Chehl-Chay watershed) with special ecological, economical, and social conditions. In the study area, the numerous wild fires were occurred in the past years and fire suppression had very difficulties. By the way, in forested watershed areas, for road designing and constructing are generally considered only settlement accessing and traveling need without covering other needs such as disaster (like wildfires) management. The aim and novelty of the study is assessment the current road network situation and its spatial position for fire management.

According to results, the about two third of occurred fires are located in the distances of close to roads and in HHC class that they happened in fall season. Although, based on road network analysis results, the road density in forests is less than the other land uses, but the most of forest land cover is located in the high and relative hazard zones. This result indicates that forests are dangerous areas for fire and be the more fire prone land use due to preparing fire fuel.

As it is stated in the introduction, the most of forest fires occurred in the bottom to middle of watershed, and the forest land cover where people and eco-tourists are interesting to settle in these places. In addition, the studied area is a mountainous watershed and elevation above sea level is ranging 190 to $2750 \mathrm{~m}$. Therefore, the temperature and humidity is very hot and low in the bottom to middle of watershed in the summer and fall. With these causes, in the forest land covers, the risk of fire is always high due to be prepare fire fuel and flammability.

The road type analysis showed that most of roads in the forest areas are asphalt roads. Based on these results, it can be concluding that types of road and land cover are important both in fire occurring, and in fire prevention and fire suppression in wild land. The one reason for fires occurrence in the areas close to the asphalt roads is fast and comfortable accessing and travelling the people and passing with all of vehicles and high ratio of traffic and high density of population (local community and tourists) inhabits the edge of roads. However, there are some difficulties and limitations for traveling in the gravel and dirt roads. In other hand, based on road passing analysis results, the roads do not cover close to half of watershed area as well as don't pass at the two third of high hazard class zone. Therefore, appreciate road network planning and designing for studied area is necessary according to fire-fighting management or using of suitable fighting fire vehicles for forest mountainous region.

This study concluded that in the forest and watershed road network designing and planning in watershed and landscape levels, the integrated watershed management goals such as wildfire fighting accessibility and other roads services should be considered particularly in the spatial domains. It is a work that can be done everywhere with the same kind of problems and can help to solve problems of fire risk and extinction to the fire fighters or/and authorities.

\section{References}

Adab, H.; Kasturi, Devi, K; Solaiman, K. 2013 Modeling forest fire hazard in the northeast of Iran using remote sensing and GIS techniques, Nat Hazards 65: 1723-1743. https://doi.org/10.1007/s11069-012-0450-8

Amatulli, G.; Per'ez-Cabelloa, F.; Rivaa, J. 2007. Mapping lightning/human-caused wildfires occurrence under ignition point location uncertainty, Ecological Modeling 200: 321-33.

Arienti, M. C.; Cumming, S. G.; Krawchuk, M. A.; Boutin, S. 2009. Road network density correlated with increased lightning fire incidence in the Canadian western boreal forest, International Journal Wild Land Fire 18(8): 970-982. https://doi.org/10.1071/WF08011

Arndt, N.; Vacik, H.; Koch, V.; Arpaci, V.; Gossow, H. 2013. Modeling human-caused forest fire ignition for assessing forest fire danger in Austria, iForest - Biogeosciences and Forestry 6: 315-325.

Arpaci, A.; Malowerschni, B.; Sass, O.; Vacik, H. 2014. Using multi variate data mining techniques for estimating fire susceptibility of Tyrolean forests, Applied Geography 53: 258270. https://doi.org/10.1016/j.apgeog.2014.05.015

Avila-Flores, D.; Pompa-Garcia, M.; Antonio-Nemiga, X.; Rodriguez-Trejo, D. A.; Vargas-Perez, E.; Perez, J. 2010. Driving factors for forest fire occurrence in Durango State of Mexico: a geospatial perspective, China Geogra Science 20(6): 491497. https://doi.org/10.1007/s11769-010-0437-x

Barni, P. E.; Pereira, V. B.; Manzi, A. O.; Barbosa, R. I. 2015. Deforestation and Forest fires in Roraima and their relationship with phytoclimatic regions in the northern Brazilian Amazon, Environmental Management 55(5): 1124-1138. https://doi.org/10.1007/s00267-015-0447-7

Bisquert, M.; Caselles, E.; Sánchez, J. M.; Caselles, V. 2012. Application of artificial neural networks and logistic regression to the prediction of forest fire danger in Galicia using MODIS data, International Journal Wild land Fire 21(8): 1025-1029. https://doi.org/10.1071/WF11105 
Boubeta, M.; Jose Lombardía, M.; Marey-Perez, F. M.; Morales, D. 2015. Prediction of forest fires occurrences with area-level Poisson mixed models, Journal Environmental Management 154: 151-158.

https://doi.org/10.1016/j.jenvman.2015.02.009

Bowyer, C.; Withana, S.; Fenn, I.; Bassi, S.; Lewis, M.; Cooper, T. 2009. Land degradation and desertification, Policy Department Economic and Scientific Policy, 34-50.

Carmelm, Y.; Paz, S.; Jahashan, F.; Shoshany, M. 2009. Assessing fire hazard using Monte Carlo simulations of fire spread, Forest Ecology and Management 257(1): 370-377. https://doi.org/10.1016/j.foreco.2008.09.039

Carmo, M.; Moreira, M.; Casimiro, P.; Vaz, P. 2011. Land use and topography influences on wildfire occurrence in northern Portugal, Landscape and Urban Planning 100(1-2): 169-176. https://doi.org/10.1016/j.landurbplan.2010.11.017

Češljar, G.; Stevović, S. 2015. Small reservoirs and their sustainable role in fires protection of forest resources, Renewable and Sustainable Energy Reviews 47: 496-503. https://doi.org/10.1016/j.rser.2015.03.071

Chas-Amil, M. L.; Touza, J.; García-Martínez, E. 2013. Forest fires in the wild land-urban interface: a spatial analysis of forest fragmentation and human impacts, Applied Geography 43: 127-137. https://doi.org/10.1016/j.apgeog.2013.06.010

Chen, H.; Yuanman, H.; Yu, C.; Rencang, B.; Yuehui, L.; Miao, L. 2015. Changes of forest fire regime and landscape pattern under different harvesting modes in a boreal forest of Northeast China, Journal Arid Land 7(6): 841-851. https://doi.org/10.1007/s40333-015-0015-2

Chen, J. Q.; Franklin, J. F.; Spies, T. A. 1993. Contrasting microclimates among clear-cut, edge, and interior of old-growth Douglas-fir forest, Agricultural and Forest Meteorology 63: 219-237. https://doi.org/10.1016/0168-1923(93)90061-L

Chen, J.; Di, X. Y. 2015. Forest fire prevention management legal regime between China and the United States, Journal of Forest Research 26(2): 447-455. https://doi.org/10.1007/s11676-015-0067-3

Çoban, H. O.; Eker, M. 2010. Analysis of forest road network conditions before and after forest fire, in FORMEC 2010, Forest Engineering: Meeting the Needs of the Society and the Environment, 11-14 July 2010, Padova, Italy. 11 p.

Cortez, P.; Morais, A. 2007. A data mining approach to predict forest fires using meteorological data, in J. Neves, M. F. Santos, J. Machado (Eds.). New trends in artificial intelligence. Proceedings of the $13^{\text {th }}$ EPIA 2007 - Portuguese Conference on Artificial Intelligence, December 2007, Guimarães, Portugal, 512-523.

Cottle, P. 2007. Insuring Southeast Asian commercial forests: fire hazard analysis and the potential for use of data in hazard pricing and reduction of forest fire hazard, Mitig Adapt Strat Glob Change 12: 181-201. https://doi.org/10.1007/s11027-006-9042-9

Deng, O.; Su, G. F.; Huang, Q, Y.; Li, Q. Y. 2013. Forest fire hazard mapping based on spatial logistic model of northeastern China forest zone. Springer-Verlag Berlin Heidelberg, 181-192.

Dlamini, W. M. 2010. Application of Bayesian networks for fire hazard mapping using GIS and remote sensing data, Geo Journal 76: 283-296. https://doi.org/10.1007/s10708-010-9362-X

Dong, X.; Shao, G.; Limin, D.; Zhanqing, H.; Lei, T.; Hui, H. 2006. Mapping forest fire risk zones with spatial data and principal component analysis, Science in China: Series E Technological Sciences 49: 140-149.

FAO. 2007. Fire management global assessment 2006. FAO forestry paper. FAO Rome Italy. 119 p.

Forman, R. T.; Alexander, L. E. 1998. Roads and their major ecological effects, Annual Review of Ecology and Systematics 29: 207-231. https://doi.org/10.1146/annurev.ecolsys.29.1.207

Fox, D. M.; Martin, N.; Carrega, P.; Andrieu, J.; Adnesm, C.; Emsellem, K.; Ganga, O.; Moebius, F.; Tortorollo, N.; Fox, E. A. 2015. Increases in fire hazard due to warmer summer temperatures and wild land urban interface changes do not necessarily lead to more fires, Applied Geography 56: 1-12. https://doi.org/10.1016/j.apgeog.2014.10.001

Guo, F.; Su, Z.; Wang, G.; Sun, L.; Lin, F.; Liu, A. 2016. Wildfire ignition in the forests of southeast China: identifying drivers and spatial distribution to predict wildfire likelihood, Applied Geography 66: 12-21. https://doi.org/10.1016/j.apgeog.2015.11.014

Hernandez-Leal, P. A.; Arbelo, M.; Gonzalez-Calvo, A. 2006. Fire hazard assessment using satellite data, Advances in Space Research, 37: 741-746. https://doi.org/10.1016/j.asr.2004.12.053

Hoyo, L, V.; Martin Isabel, M. P.; Martınez Vega, F. J. 2011. Logistic regression models for human-caused wildfire hazard estimation: analyzing the effect of the spatial accuracy in fire occurrence data, European Journal Forest Research 130: 983996. https://doi.org/10.1007/s10342-011-0488-2

Jaiswal, R. K.; Mukherjee, S.; Raju, D. K.; Saxena, R. 2002. Forest fire hazard zone mapping from satellite imagery and GIS, International Journal of Applied Earth Observation and Geoinformation 4: 1-10. https://doi.org/10.1016/S0303-2434(02)00006-5

Kapusniak, J.; Majlingová, A. 2014. Results of forest opening-up analysis for ground mobile fire-fighting equipment deployment in LS Maluzina territory - Case study, European Journal of Environmental and Safety Sciences 2(2): 37-47.

Kuter, N.; Yenilmez, F.; Kuter, S. 2011. Forest fire hazard mapping by kernel density estimation, Croatian Journal Forest Engineering 32(2): 599-610.

Kwak, K.; Leea, W. K.; Saborowskibm, J.; Leecm, S. Y.; Soo, M. 2012. Estimating the spatial pattern of human-caused forest fires using a generalized linear mixed model with spatial autocorrelation in South Korea, International Journal Geographical Information Science 26(9): 1589-1602. https://doi.org/10 $.1080 / 13658816.2011 .642799$

Lee, S. Y.; Won, M. S.; An, S. H.; Lee, M. B .2004. Developing of forest fire occurrence probability model by using the meteorological characteristics in Korea, Korean Journal of Agricultural and Forest Meteorology 6(4): 242-249.

Liu, X.; Zhang, J.; Tong, T. 2015. Modeling the early warning of grassland fire hazard based on fuzzy logic in Xilingol Inner Mongolia, Nat Hazards 75: 2331-2342. https://doi.org/10.1007/s11069-014-1428-5

Maingi, K. J.; Henry, M. C. 2007. Factors influencing wildfire occurrence and distribution in eastern Kentucky, USA, International Journal Wildland Fire 16(1): 23-33. https://doi.org/10.1071/WF06007

Martinez, J.; Vega-Garciam, C.; Chuvieco, E. 2009. Humancaused wildfire hazard rating for prevention planning in Spain, Journal of Environmental Management 90(2): 12411252. https://doi.org/10.1016/j.jenvman.2008.07.005 
Massada, A. B.; Syphard, A. D.; Stewart, S. I.; Radeloff, V. C. 2013. Wildfire ignition-distribution modeling: a comparative study in the Huron-Manistee National Forest, Michigan, USA, Journal of Environmental Management 22(2): 174-183.

Narayanaraj, G.; Wimberly, M. C. 2011. Influences of forest roads on the spatial pattern of wildfire boundaries, International Journal of Wildland Fire 20(6): 792-803.

Narayanaraj, G.; Wimberly, M. C. 2013. Influences of forest roads and their edge effects on the spatial pattern of burn severity, International Journal of Applied Earth Observation and Geoinformation 23: 62-70.

https://doi.org/10.1016/j.jag.2012.12.006

Nasiri, M. 2012. Skidding routes simulation for opening access to high-hazard fire areas, World Applied Sciences Journal 16(6): 791-798.

Nunes, A. N. 2012. Regional variability and driving forces behind forest fires in Portugal an overview of the last three decades, Applied Geography 34: 576-586. https://doi.org/10.1016/j.apgeog.2012.03.002

Oliveira, S.; Oehler, F.; San-Miguel-Ayanz, J.; Camia, A.; Pereira, J. M. C. 2012. Modeling spatial patterns of fire occurrence in Mediterranean Europe using Multiple Regression and Random Forest, Forest Ecology and Management 275: 117-129. https://doi.org/10.1016/j.foreco.2012.03.003

Ozbygol, M. A., Bozer, R. 2012. Estimation of the burned area in forest fires using computational intelligence techniques, Procedia Computer Science 12: 282-287. https://doi.org/10.1016/j.procs.2012.09.070

Pierce, A. D.; Farris, C. A.; Taylor, A. H. 2012. Use of random forests for modeling and mapping forest canopy fuels for fire behavior analysis in Lassen Volcanic National Park, California, USA, Forest Ecology and Management 279: 77-89. https://doi.org/10.1016/j.foreco.2012.05.010

Pourghasemi, H. R.; Beheshtirad, M.; Pradhan, B. 2016. A comparative assessment of prediction capabilities of modified analytical hierarchy process (M-AHP) and Mamdani fuzzy logic models using Netcad-GIS for forest fire susceptibility mapping, Geomatics, Natural Hazards and Hazard 7(2): 861885. https://doi.org/10.1080/19475705.2014.984247

Reineking, B.; Weibel, P.; Conedera, M.; Bugmann, H. 2010. Environmental determinants of lightning- v. human-induced forest fire ignitions differ in a temperate mountain region of Switzerland, International Journal of Wildland Fire 19(5): 541-557. https://doi.org/10.1071/WF08206

Renard, Q.; Pelissier, R.; Ramesh, B. R.; Kodandapani, N. 2012. Environmental susceptibility model for predicting forest fire occurrence in the Western Ghats of India, International Journal of Wildland Fire 21(4): 368-379. https://doi.org/10.1071/WF10109

Roman, C. R.; Martinez, V. M. J. 2006. Effectiveness of protected areas in mitigating fire within their boundaries: case study of Chiapas, Mexico, Conservation Biology 20(4): 1074-1086. https://doi.org/10.1111/j.1523-1739.2006.00478.x

Pourtaghi, Z. S.; Pourghasemi, H. R.; Rossi, M. 2015. Forest fire susceptibility mapping in the Minudasht forests, Golestan province, Iran, Environ Earth Science 73(4): 1515-1535. https://doi.org/10.1007/s12665-014-3502-4
Safi, Y.; Bouroumi, A. 2013. Prediction of Forest Fires Using Artificial Neural Networks, Applied Mathematical Sciences 7(6): 271- 286. https://doi.org/10.12988/ams.2013.13025

Sahu, M. 2015. Integrating artificial neural network with machine learning in forecasting problem domain, International Journal of Recent Research Aspects 2(2): 8-11.

Sakr, G. E.; Elhajj, I. H.; Mitri, G. 2010. Artificial intelligence for forest fire prediction: a comparative study, in D. X. Viegas (Ed.). $6^{\text {th }}$ International Conference on Forest Fire Research, 15-18 November 2010, Coimbra, Portugal, 1-11. https://doi.org/10.1109/aim.2010.5695809

Sakr, G.; Elhajj, E. I. H.; Mitri, G. 2011. Efficient forest fire occurrence prediction for developing countries using two weather parameters, Engineering Applications of Artificial Intelligence 24: 888-894. https://doi.org/10.1016/j.engappai.2011.02.017

Schonewald-Cox, C. M.; Buechner, M. 1992. Park protection and public roads, in P. L. Fiedler, S. Jain (Eds.). Conservation biology. The theory and practice of nature conservation, preservation and management. Chapman and Hall, New York, 373-396. https://doi.org/10.1007/978-1-4684-6426-9_15

Soto, M. E. C. 2012. The identification and assessment of areas at hazard of forest fire using fuzzy methodology, Applied Geography 35: 199-207. https://doi.org/10.1016/j.apgeog.2012.07.001

Spellerberg, I. F. 2002. Ecological Effects of Roads. Science Publisher, Inc., Enfield, USA.

Tian, X.; Zhao, F.; Shu, L.; Wang, M. 2013. Distribution characteristics and the influence factors of forest fires in China, Journal of Forest Ecology and Management 310: 460-467. https://doi.org/10.1016/j.foreco.2013.08.025

Tuček, J.; Majlingová, A. 2009. Forest fire vulnerability analysis, in Střelcová K. et al. (Eds.). Bioclimatology and natural hazards. Springer: Dordrecht, 219-230. https://doi.org/10.1007/978-1-4020-8876-6_19

Vasilakos, C.; Kalabokidis, K.; Hatzopoulos, J.; Matsinos, I. 2009. Identifying wild land fire ignition factors through sensitivity analysis of a neural network, Nat Hazards 50: 125-143. https://doi.org/10.1007/s11069-008-9326-3

Verma, A. K.; Singh, D.; Sharma, S. D.; Kamlesh, K. 2013. Forest Fire Hazard Zonation in Raipur Range, Missouri Forest Division using GIS and Remote Sensing Technology, International Journal of Advanced Scientific and Technical Research 3(6): 141-150.

Wu, Zh.; Hem, H. S.; Yang, J.; Liang, Y. 2015. Defining fire environment zones in the boreal forests of Northeastern China, Science of the Total Environment 518-519: 106-116. https://doi.org/10.1016/j.scitotenv.2015.02.063

Zhang, Z. X.; Zhang, H. Y.; Zhou, D. W. 2010. Using GIS spatial analysis and logistic regression to predict the probabilities of human-caused grassland fires, Journal of Arid Environments 74: 386-393. https://doi.org/10.1016/j.jaridenv.2009.09.024

Zumbrunnen, T.; Menendez, P.; Bugmann, H.; Conedera, M.; Gimmi, U.; Burgi, M. 2012. Human impacts on fire occurrence: a case study of hundred years of forest fires in a dry alpine valley in Switzerland, Regional Environmental Change 12: 935-949. https://doi.org/10.1007/s10113-012-0307-4 
Mohsen MOSTAFA. PhD student of forest sciences. He is studying on forest road network designing based on watershed management needs and goals particularly in relationship between road and fire. Gorgan University of Agricultural Sciences and Natural Resources (GUASNR), Iran.

Shaban SHATAEE JOUIBARY. PhD. Specializing in forest remote sensing. Associate Professor, GUASNR. He received his $\mathrm{PhD}$ from Tehran University in 2002. His research interesting is including using remote sensing in natural resources and natural hazard. He published more than 80 papers in national and international scientific journals in remote sensing, GIS and forestry categories. Now he is dean of faculty of forest sciences, Gorgan University of Agricultural Sciences and Natural Resources (GUASNR), and chief editor of Journal of Conservation and Utilization of Natural Resources in GUASNR.

Majid LOTFALIAN. PhD. Specializing in forest engineering. Associate Professor at Sari University of Agricultural Sciences and Natural Resources, Sari, Iran. He received his PhD from Tehran University in 2000. His research interesting is including forest road and forest harvesting. Now he is head of forestry department, natural resources faculty, University of Agricultural Sciences and Natural Resources, Sari, Iran.

Amir SADODDIN. PhD. Specializing in watershed management. Associate Professor, GUASNR. He received his PhD from National University, Australia, in 2006. His research interesting is including watershed management. He was dean of Faculty of Rangeland and Watershed Management of GUASNR. Currently he is manger of the National Mega Project on the integrated watershed management in Iran. 